\title{
Assessment of Technical and Ecological Parameters of a Diesel Engine in the Application of New Samples of Biofuels
}

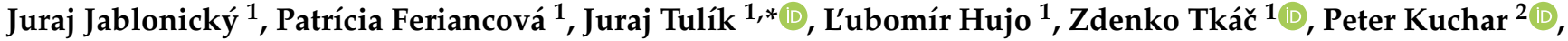 \\ Milan Tomić ${ }^{3}$ and Jerzy Kaszkowiak ${ }^{4}$
}

1 Department of Transport and Handling, Faculty of Engineering, Slovak University of Agriculture in Nitra, Tr. A. Hlinku 2, 94976 Nitra, Slovakia; juraj.jablonicky@uniag.sk (J.J.); xferiancova@uniag.sk (P.F.); lubomir.hujo@uniag.sk (L'.H.); zdenko.tkac@uniag.sk (Z.T.)

2 Department of Building Equipment and Technology Safety, Faculty of Engineering, Slovak University of Agriculture in Nitra, Tr. A. Hlinku 2, 94976 Nitra, Slovakia; peter.kuchar@uniag.sk

3 Department of Agricultural Engineering, Faculty of Agriculture, University of Novi Sad, Dr Zorana Đinđića 1, 21102 Novi Sad, Serbia; milanto@polj.uns.ac.rs

4 Faculty of Mechanical Engineering, University of Technology and Life Sciences in Bydgoszcz, Al. Prof. S. Kaliskiego 7, 85-789 Bydgoszcz, Poland; kaszk@utp.edu.pl

* Correspondence: juraj.tulik@uniag.sk; Tel.: +421-37-641-4531

\section{check for}

updates

Citation: Jablonický, J.; Feriancová,

P.; Tulík, J.; Hujo, L.; Tkáč, Z.; Kuchar,

P.; Tomić, M.; Kaszkowiak, J.

Assessment of Technical and

Ecological Parameters of a Diesel

Engine in the Application of New

Samples of Biofuels. J. Mar. Sci. Eng.

2022, 10, 1. https://doi.org/

10.3390/jmse10010001

Academic Editor: María Isabel Lamas Galdo

Received: 9 November 2021

Accepted: 19 December 2021

Published: 21 December 2021

Publisher's Note: MDPI stays neutral with regard to jurisdictional claims in published maps and institutional affiliations.

Copyright: (C) 2021 by the authors. Licensee MDPI, Basel, Switzerland. This article is an open access article distributed under the terms and conditions of the Creative Commons Attribution (CC BY) license (https:// creativecommons.org/licenses/by/ $4.0 /)$.

\begin{abstract}
The technical and environmental parameters of the diesel internal combustion engine using two new samples of biofuels SAMPLE 1 and SAMPLE 2 were evaluated in this paper. SAMPLE 1 and SAMPLE 2 biofuels were tested on a LOMBARDINI LDW 502 internal combustion engine, which was loaded on a dynamometer according to the applicable national and international standards. This method can also be applied to marine engines and contribute to a higher level of marine ecology. The result of the testing was to determine the impact of tested biofuels on the technical parameters engine power and torque and the environmental parameters emissions of smoke, nitrogen oxides, and economy of the internal combustion engine-specific fuel consumption. From the measured data, another parameter was calculated, such as the injected fuel dose and the overall efficiency of the internal combustion engine. The results show that the new samples of SAMPLE 1 and SAMPLE 2 biofuels tested could be a suitable alternative to standard diesel.
\end{abstract}

Keywords: emissions; alternative fuels; combustion engine; environment

\section{Introduction}

At present, the issue of environmental studies and energy is one of the serious problems in society [1,2]. Transport has a significant impact on the creation of undesirable emissions as well as energy load. Depending on the level of motorization, the transport sector contributes to air pollution $\left(\mathrm{CO}_{2}\right)$ in the range of approximately $11 \%$ [3]. The main share of liquid driving fuel falls on road and rail transport. Energy consumption in transport is increasing both in absolute terms, i.e., in energy units, but also in relative terms, which can be characterized as its share in the total energy consumption of all sectors in all major regions of the world [4]. At present, the transport sector contributes circa $32 \%$ of the EU's energy consumption. We can therefore state that the transport sector is one of the most demanding in terms of energy consumption [5].

The power unit in mobile energy used in transport is an internal combustion engine. One of the disadvantages of an internal combustion engine is the products of combustion, i.e., exhaust emissions. Exhaust emissions from a diesel engine have a negative impact on the environment as well as on humans [6]. These are mainly emissions of pollutants, especially "greenhouse" gases, which cause gradual irreversible warming of the planet and disequilibriate in nature with acid rain. This is mainly carbon dioxide $\mathrm{CO}_{2}$, nitrogen oxides $\mathrm{NO}_{X}$, methane $\mathrm{CH}_{4}$, and sulfur oxides $\mathrm{SO}_{X}$ [7]. The exhaust gases of a diesel engine form a complex mixture of compounds present in the solid and gaseous phases and 
include certain classes of compounds, such as polycyclic aromatic hydrocarbons, many of which are genotoxic. These gases are released into the air by burning fossil fuels (crude oil, coal, and natural gas) [8]. The European Community, as the regulatory authority for motor vehicles, has been setting limit requirements for vehicles for more than 20 years in terms of their environmental impact [9]. Arrangements have been proposed to achieve the goal of reducing greenhouse gas emissions, which should replace up to $10 \%$ of standard hydrocarbon fuels in biofuels in the near future. Many technologies are currently being used to reduce particulate emissions, including engine constructional modifications, emission control devices, and the use of alternative fuels [10].

The composition of exhaust gases and the proportion of the individual components of the diesel engine are relatively balanced [11]. During the technical life of the engine, there are no gradual changes in the difference in the proportions of individual components in all modes of engine operation. A change in the technical condition of the engine affecting the quality of the mixture preparation or the conditions of the combustion process causes an increase in the production of CO resp. HC. This is reflected, on the one hand, in a decrease in the effective pressure, and thus in an improvement in the conditions for reducing the content of nitrogen oxides $\mathrm{NO}_{\mathrm{X}}$, and, on the other hand, a change in the temperature balance has the effect of increasing the production of solid particles. It is clear from this that the deterioration of the technical condition of the engine while maintaining the transport characteristics of the injection pump will be reflected in a decrease in the engine torque while maintaining hourly fuel consumption and thus an increase in specific fuel consumption. This condition is reflected in a change in the shares of individual pollutants in the exhaust emission, namely by a decrease in the proportion of $\mathrm{NO}_{X}$ and an increase in the proportions of $\mathrm{CO}$ and $\mathrm{HC}$ with a simultaneous increase in the smoke of the engine [12].

The possibility of creating new emissions should also be considered if additives are applied to the fuel or lubricating oil and where fluids are introduced into the exhaust gases. A well-known example is urea used to reduce $\mathrm{NO}_{X}$ emissions in an SCR catalyst. SCR can include ammonia, as well as a number of substances from incomplete decomposition of urea [13].

One way to comply with stricter emissions regulations is to focus attention and look for suitable alternative fuels as reported by [14] in his publication. According to these authors, the main alternative fuels used in automobile transport could be ethanol, hydrogen, and biodiesel. A large number of studies have shown that biodiesel could be an alternative fuel, which is one of the fuels that could be used in diesel engines with little or no treatment requirements with little or no adjustment requirements [15]. It has been proven that biodiesel has significant potential for reducing $\mathrm{CO}_{2}, \mathrm{CO}, \mathrm{THC}$, and PM emissions $[16,17]$. Studies on biodiesel have been extensively researched due to their attributes of ecological and economic viability and their aspects [18]. Biodiesel consists of various organic substances. These substances can be combined with fuel in various ratios [19]. It is not necessary to modify the diesel engine to use biodiesel, because the properties of biodiesel are similar to conventional fuels. The advantage of biodiesel is that it is a renewable energy source, biodegradable, environmentally friendly, non-explosive, and produces less emissions [20]. The main components of biodiesel are cooking oil, vegetable waste and oils, and animal fats. The use of these oils and fats is inconvenient without further treatment because they have a higher viscosity than normal crude oil [21]. Biofuel sources are divided into edible (sunflower oil, peanut oil, coconut oil, palm oil, etc.) and inedible (jojoba, jatropha, cotton, moringa, etc.) sources [22]. Studies have shown that a mixture of biodiesel reduces emissions of gases (CO, PM, and HC) that are toxic to the environment and increase air pollution [21]. When comparing biofuels with conventional oil, both substances have the same physicochemical properties. Thanks to these properties, the engine needs only a small modification [23]. Mixing diesel with inedible oil increases the given properties of the fuel. Antony et al. studied the combination of fuel with candle and mind oil. This combination showed reduced $\mathrm{CO}, \mathrm{CO}_{2}, \mathrm{HC}$, and $\mathrm{NO}_{\mathrm{X}}$ emissions compared to pure diesel [24]. The authors Sharma et al., researched the 
energy and emission parameters of the hydroxyl diesel engine. These results revealed that $\mathrm{CO}$, unburned hydrocarbon, and smoke emissions were reduced, and $\mathrm{NO}_{\mathrm{X}}$ emission enhanced [25]. The authors Sarıkoç et al. investigated the performance of the diesel engine with different biodiesel and diesel-butanol blends. These results revealed that biodiesel increases the energy efficiency and that $75 \%$ diesel, $20 \%$ biodiesel, and $5 \%$ butanol is the best fuel ratio for sustainability parameters [26]. The authors Gad et al. performed an analysis of a diesel engine with waste cooking oil biodiesel and gasoline. These results revealed that the addition of gasoline reduces the opacity of $\mathrm{CO}, \mathrm{NO}_{\mathrm{X}}$, unburned hydrocarbon, and smoke and that a mixture of $92 \%$ waste cooking oil and $8 \%$ gasoline is the best combination in terms of the performance and emission characteristics [27]. Alternative fuels made from agricultural products have a higher oxygen content compared to diesel. The authors Ramadhas et al. state that the use of mixtures of methyl esters of vegetable oils achieves the same engine power as diesel at full load conditions, as well as the average load at different engine speeds [28]. The authors Qi et al. and Frijters \& Baert agree that the lower heat value of biodiesel must be offset by its higher consumption. The performance of an internal combustion engine is affected by the properties of the biofuel, in particular its heat value, viscosity, and lubricating properties $[29,30]$.

It can be stated that alternative fuels or their mixtures formed with diesel are constantly the subject of research, with a focus on reducing emissions arising from their combustion in the engine, but also the conversion of their heat energy into mechanical work [31]. Currently, researchers are involved in environmental protection and the production of biofuels and its use in various equipment [32]. Many research articles on energy, emission, and combustion analysis of biodiesel engines are available, such as [33,34].

\section{Materials and Methods}

\subsection{Test Conditions for Engines in Laboratory Conditions}

According to ISO 2288, STN 30 0415, and STN ISO 789-1 (30 0411), the conditions for testing tractor engines in laboratory conditions are as follows:

- The test must be performed at the set full fuel dose on the injection pump;

- The test shall be performed on the engine after running-in, as consistent with the manufacturer's recommendations, under conditions of stable engine operation;

- When preparing the engine for the tests, a setting must be made, which must not be changed during the tests;

- Engines supplied for testing must be equipped completely according to the manufacturer's enclosed technical documentation, with documents of acceptance by the technical inspection of the production company and the running-in protocol;

- All repair principles and deficiencies must be recorded during the tests;

- The atmospheric conditions of the test should be as close as possible to the reference to reduce the value of the correction factor. This represents an atmospheric pressure of $96.6 \mathrm{kPa}$ and a temperature of $23 \pm 7^{\circ} \mathrm{C}$;

- The temperature of the air entering the engine must be measured at a maximum distance of $0.15 \mathrm{~m}$ from the inlet. The temperature sensor should be protected from radiant heat and placed in the air flow;

- The countdown can only take place when the torque, speed, and temperature are approximately constant for at least one minute;

- The speed value after setting it must not change $\Delta n= \pm 1 \%$ or $10 \mathrm{~min}^{-1}$, taking into account the higher value;

- The average value of two stable measurements (differing by a maximum of $2 \%$ ) of load, consumption, and intake air temperature shall be recorded;

- For temperature and speed measurements, a minimum measurement time of $30 \mathrm{~s}$ is set for automatic measurement and $50 \mathrm{~s}$ for manual measurement;

- Unless otherwise specified by the manufacturer, the outlet coolant temperature shall be $80 \pm 5^{\circ} \mathrm{C}$ and the oil temperature shall be between 80 and $100{ }^{\circ} \mathrm{C}$ for air-cooled 
engines, and the temperature must be maintained at the exact location specified by the manufacturer with a tolerance of $\pm 20^{\circ} \mathrm{C}$;

- The fuel temperatures at the inlet to the injection pump and crankcase (or at the outlet from the oil cooler) must be within $\Delta t \pm 5{ }^{\circ} \mathrm{C}$ of the temperature specified by the engine manufacturer with a minimum value of $30^{\circ} \mathrm{C}$;

- The exhaust outlet temperature must be measured at the exhaust flange and must be within the specified range;

- The exhaust system in the test cell must not, during engine operation, generate a pressure other than atmospheric pressure with a tolerance of $\Delta p \pm 740 \mathrm{~Pa}$ (measured at the connection point);

- The cooler, blower, water pump, and thermostat must be located as mounted on the vehicle during the test;

- Auxiliary equipment is specified, which must be included in the test; others must be excluded during the test;

- $\quad$ Engine tests should be performed without interruption. When it is necessary to shut down the engine during the tests, it must be ensured that it warms up to the prescribed steady values [35].

The accelerator pedal was pressed quickly but non-violently (at most in $1 \mathrm{~s}$ ) to achieve the maximum fuel quantity, and it was released until the maximum rpm had been reached and recorded by the device, i.e., until approximately $2 \mathrm{~s}$ after reaching them. After releasing the accelerator pedal, a decrease in speed was expected, which could not be higher than the value of idling speed. Subsequently, the values of the absorption coefficient, idle rpm, maximum speed, and acceleration time were recorded. Free acceleration was performed 3 times, and the time between two successive presses of the accelerator pedal was at least 10 s. A flow meter from EMICRON DMS 1 was used to measure consumption, which measures with an accuracy of up to $1 \%$. The accuracy of the dyno is $2 \%$.

\subsection{Characteristics of the Measured Object}

An Italian-made LOMBARDINI LDW 502 diesel engine, which meets the EURO 2 emission standard, was used for the measurement. The LOMBARDINI LDW 502 engine is a water-cooled four-stroke in-line twin-cylinder with direct fuel injection and a pump-nozzle injection system. The engine distribution is an overhead valve and there are two valves per cylinder. The engine is not supercharged. The basic parameters of engine are in Table 1.

Table 1. Basic technical parameters of the LOMBARDINI LDW 502 engine.

\begin{tabular}{cc}
\hline Parameter Name & Values \\
\hline Number of engine cylinders, pcs & 2 \\
Engine capacity, $\mathrm{cm}^{3}$ & 505 \\
Cylinder diameter, $\mathrm{mm}$ & 72 \\
Stroke, mm & 62 \\
Compression ratio, - & $22.8: 1$ \\
Combustion order, & 360 \\
Engine power (according to 80/1269/CEE), ISO 1585, $\mathrm{kW} / \mathrm{HP}$ & $4.0 / 5.43$ \\
Maximum torque, Nm & 20 \\
Rpm at maximum torque, $\min ^{-1}$ & 1600 \\
Engine idle, min $^{-1}$ & $950-1100$ \\
Nominal rpm, $\min ^{-1}$ & 3000 \\
Maximum rpm, $\mathrm{min}^{-1}$ & 3400 \\
Water pump flow at $3400 \mathrm{~min}^{-1}, \mathrm{dm}^{3}$ & 40 \\
Air consumption at $3400 \mathrm{~min}^{-1}, \mathrm{dm}^{3}$ & 910
\end{tabular}

The emission state of the combustion engine was measured with an exhaust gas analyzer MET 6.3 from MAHA. The meter operates with an expanded measurement uncertainty $U$, which is expressed as the standard measurement uncertainty multiplied by the overlap coefficient $k=2$, which, under a normal distribution, corresponds to a 
probability of coverage of approximately 95\% and was set according to MSA 0104-97, respectively EA-4/02 M:2013.

The basic technical data of the emission analyzer MET 6.3 are listed in Table 2.

Table 2. Technical data of the emission analyzer MET 6.3.

\begin{tabular}{cc}
\hline Measurable Gases & $\mathrm{HC}, \mathrm{CO}, \mathrm{CO}_{2}, \mathbf{O}_{2}, \mathbf{N O}, \mathrm{NO}_{2}, \mathbf{N O x}$ \\
\hline Flow & $3.5 \mathrm{dm}^{3} \mathrm{~min}^{-1}$ \\
Accuracy class & $\mathrm{O}(\mathrm{OIML})$ \\
Measurement principle & Absorbance measurement \\
Warm-up time of the measurement chamber approx. & $150 \mathrm{~s}$ \\
Measuring range particle concentration & $1-1100 \mathrm{mg} \cdot \mathrm{m}^{-3}$ \\
Resolution of particle concentration & 1 \\
Measurement range turbidity & $0-100 \%$ \\
Measuring range absorption coefficient & $0-9.99 \mathrm{~m}^{-1}$ \\
Resolution absorption coefficient & $9.99 \mathrm{~m}^{-1}$ \\
On-board voltage & $10 \mathrm{~V} / 30 \mathrm{~V}$ \\
Power supply & $0-45^{\circ} \mathrm{C}$ \\
Ambient temperature & $1 / \mathrm{N} / \mathrm{PE} 110 \mathrm{~V} / 230 \mathrm{~Hz} / 60 \mathrm{~Hz}$ \\
\hline
\end{tabular}

The aim was to assess new samples of biofuels with a focus on the technical-operational parameters, emission parameters, and fuel consumption in accordance with the requirements of the manufacturer of alternative fuels by the designed laboratory device (Figure 1).

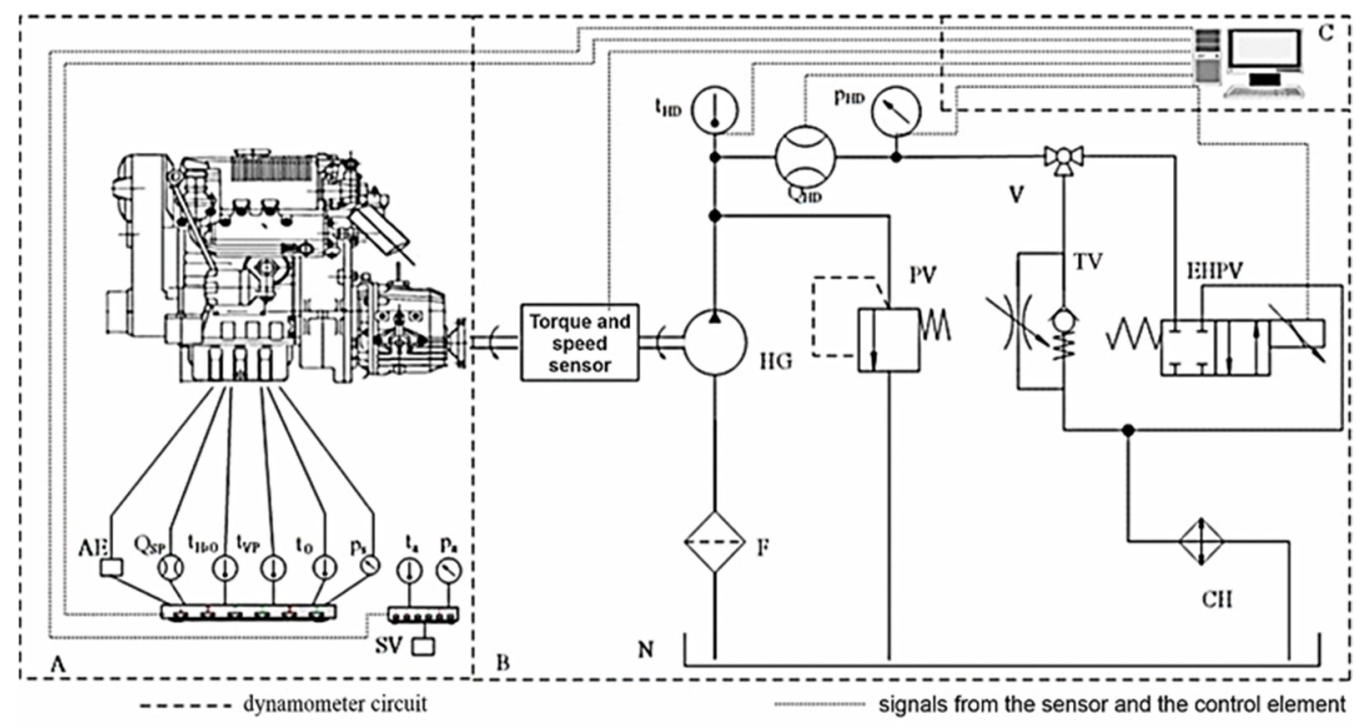

Figure 1. Experimental installation. A-internal combustion engine connection circuit, Bhydrostatic dynamometer circuit, $\mathrm{C}$-measuring and evaluation circuit, $\mathrm{N}$-tank, F-filter, HGhydrogenerator, $t_{\mathrm{HD}}$ - temperature sensor, $\mathrm{Q}_{\mathrm{HD}}$ - flow meter, $\mathrm{p}_{\mathrm{HD}}$ - pressure gauge, $\mathrm{PV}$-safety valve, V-three-way valve, TV—-throttle valve, EHPV-electrohydrostatic proportional valve, $\mathrm{CH}$ cooler, AE-emission analyzer, $\mathrm{Q}_{\mathrm{SP}}$ - fuel consumption meter-EMICRON DMS, $\mathrm{t}_{\mathrm{H}_{2} \mathrm{O}}$ - water temperature, $t_{V P}$ - exhaust gas temperature, $t_{O}$-oil temperature, $p_{s}$-intake manifold pressure, $t_{a}-$ ambient temperature, $\mathrm{p}_{\mathrm{a}}$-atmospheric pressure, $\mathrm{SV}$ - humidity sensor.

Characteristics of the Fuels Used to Monitor the Emission Status of the Combustion Engine

Samples of biofuels were provided for experimental purposes and assessment in accordance with the manufacturer. However, the manufacturer provided only the basic parameters of the samples. For this reason, only the basic fuel specification is given in the tables.

During the measurements, diesel was used in the fuel system, the basic specifications of which are listed in Table 3. 
Table 3. Diesel specification according to the standard EN 590.

\begin{tabular}{|c|c|c|c|c|}
\hline \multirow{2}{*}{ Fuel Properties } & \multirow{2}{*}{ Unit } & \multicolumn{2}{|c|}{ Specification } & \multirow[t]{2}{*}{ Test } \\
\hline & & Min & Max & \\
\hline Cetane number & & 49 & - & ISO 5165 \\
\hline Cetane index & & 46 & - & ISO 4264 \\
\hline Density at $15^{\circ} \mathrm{C}$ & $\mathrm{kg} \cdot \mathrm{m}^{-3}$ & 820 & 860 & ISO 3675/ASTM D4052 \\
\hline Sulfur content & $\%$ (weight) & - & 0.20 & EN $24260 /$ ISO 8754 \\
\hline Flash point & ${ }^{\circ} \mathrm{C}$ & 55 & - & ISO 2719 \\
\hline Carbon residues (10\% btms) & $\%$ (weight) & - & 0.30 & ISO 10370 \\
\hline Ash & $\%$ (weight) & - & 0.01 & EN 26245 \\
\hline Water content & $\mathrm{mg} \cdot \mathrm{kg}^{-1}$ & - & 200 & ASTM D1744 \\
\hline $\begin{array}{c}\text { Copper strip corrosion, } \\
3 \mathrm{~h} \text { at } 50^{\circ} \mathrm{C}\end{array}$ & & - & Class I & ISO 2160 \\
\hline Oxidation stability & $\mathrm{g} \cdot \mathrm{m}^{-3}$ & - & 25 & ASTM D2247 \\
\hline Viscosity at $40^{\circ} \mathrm{C}$ & $\mathrm{mm}^{2} \cdot \mathrm{s}^{-1}$ & 1.9 & 6.0 & ASTM D 6751 \\
\hline \multicolumn{5}{|l|}{ Distillation } \\
\hline \multicolumn{5}{|l|}{$10 \%$ point } \\
\hline $50 \%$ point & ${ }^{\circ} \mathrm{C}$ & & & ISO 3405 \\
\hline $65 \%$ point & C & 250 & - & \\
\hline $85 \%$ point & & - & $\begin{array}{l}350 \\
370\end{array}$ & \\
\hline $95 \%$ point & & - & 370 & \\
\hline
\end{tabular}

The results of technical-exploitative and emission tests were compared with the results, which were achieved by measuring the reference sample, which is diesel.

Tables 4 and 5 show the parameters of the alternative fuel SAMPLE 1 and SAMPLE 2, the new sample.

Table 4. Properties of alternative fuel SAMPLE 1.

\begin{tabular}{ccc}
\hline Properties & Unit & Determined Value \\
\hline Heat value & $\mathrm{kJ} \cdot \mathrm{kg}^{-1}$ & 39,390 \\
Density at $15^{\circ} \mathrm{C}$ & $\mathrm{kg} \cdot \mathrm{m}^{-3}$ & 880 \\
Kinematic viscosity at $40^{\circ} \mathrm{C}$ & $\mathrm{mm}^{2} \cdot \mathrm{s}^{-1}$ & 5.5 \\
Flash point & ${ }^{\circ} \mathrm{C}$ & 130 \\
Pour point & ${ }^{\circ} \mathrm{C}$ & -20 \\
Filterability & ${ }^{\circ} \mathrm{C}$ & -15 \\
Sulfur content max. & $\% \mathrm{hm} . \max$. & 0.05 \\
Cetane number & - & 55 \\
Ash content & $\% \mathrm{hm} . \max$. & 0.01 \\
Water content & $\% \mathrm{hm} . \max$. & 0.05 \\
Acid number & $\mathrm{mg} \cdot \mathrm{KOH}-1$ max. & 0.3 \\
Content mechanical impurities & $\% \mathrm{hm}$. max. & 0.005 \\
\hline
\end{tabular}

Table 5. Properties of alternative fuel SAMPLE 2.

\begin{tabular}{ccc}
\hline Properties & Unit & Determined Value \\
\hline Heat value & $\mathrm{kJ} \cdot \mathrm{kg}^{-1}$ & 40,763 \\
Density at $15^{\circ} \mathrm{C}$ & $\mathrm{kg} \cdot \mathrm{m}^{-3}$ & 880 \\
Kinematic viscosity at $40{ }^{\circ} \mathrm{C}$ & $\mathrm{mm}^{2} \cdot \mathrm{s}^{-1}$ & 4.2 \\
Flash point & ${ }^{\circ} \mathrm{C}$ & 145 \\
Pour point & ${ }^{\circ} \mathrm{C}$ & -17 \\
Filterability & ${ }^{\circ} \mathrm{C}$ & -21 \\
Sulfur content max. & $\% \mathrm{hm} . \max$. & 9.08 \\
Cetane number & - & 55.8 \\
Ash content & $\% \mathrm{hm} \cdot \max$. & 0.0035 \\
Water content & $\% \mathrm{hm} \cdot \max$. & 338 \\
Acid number & $\mathrm{mg} \cdot \mathrm{KOH}-1$ max. & 0.41 \\
Total glycerol & $\% \mathrm{hm} \cdot \mathrm{max}$. & 5 \\
Content of mechanical impurities & $\% \mathrm{hm}$. & 0.2 \\
Methyl ester content & $\% \mathrm{hm}$. & 97 \\
Phosphorus content & $\mathrm{mg} \cdot \mathrm{kg}^{-1}$ & 1.01 \\
\hline
\end{tabular}


The test methods for determining the parameters listed in Tables 4 and 5 were determined according to the following test methods: STN EN ISO 12937, STN EN 14105, STN EN ISO 12185, STN EN ISO 20846, STN EN ISO 5165, ASTM D 3231, ASTM D 6751, STN 65 6063, STN EN ISO 3104, STN EN ISO 2719, STN EN 116, STN EN ISO 10370, STN EN 14104, STN EN 12662, STN EN 14103.

\subsection{Calculation of the Correction Factor $K_{a}$ and the Motor Factor $f_{m}$}

When determining the correction factor $K_{a}$, the absolute temperature $(T)$ of the air drawn into the engine, expressed in kelvins, and the dry atmospheric pressure $(p)$ expressed in $\mathrm{kPa}$ or mbar, and according to the relations below, the parameter $K_{a}$ is determined.

Calculation of the Correction Factor for Diesel Engines without Supercharging or with Mechanical Supercharging

To calculate the correction factor for diesel engines without supercharging respectively with mechanical supercharging, relations according to DIN, EWG, ISO, SAE, and JIS standards are used. For standards EWG 80/1269, ISO 1585, SAE J1349, and JIS D1001, the calculation of the correction factor according to the relation:

$$
K_{a}=\left[\frac{990}{p} \cdot\left(\frac{T}{298}\right)^{0.7}\right]^{f m}
$$

The following applies to DIN 70020:

$$
K_{a}=\frac{1013}{p} \cdot\left(\frac{T}{293}\right)^{0.5}
$$

\subsection{Uncertainty Analysis}

The measurement uncertainty for the MET6.3 emission analyzer is $U=2$.

Mathematical Statistical Analysis of the Processing Achieved Results

The determination of the required number of repetitions of the experiment can be performed according to the given methods if the standard deviation of the measured quantity or the coefficient of variation is known in advance. These values can be known from previous measurements, preliminary control measurements, or the literature. The determination of these basic parameters of descriptive statistics is given in the following section. If the standard deviation is known, then the number of repetitions of the experiment can be determined for the selection with repetition according to Equation (3).

To determine the probability value, i.e., assumption of the occurrence of analogous results when repeating the experiment, there are no precise rules. In experiments associated with the construction of machines, a probability of $90 \%$ is required. The relationship for determining the number of repetitions can be written as follows:

$$
n=t_{a}^{2} \cdot \frac{s}{\Delta^{2}}
$$

where:

$n$ is the number of repetitions detected;

$t_{a}$ is the critical value of the normal distribution for a bilateral estimate;

$\Delta$ is the selected value of the required accuracy;

$S$ is the estimate of the standard deviation of the base set.

In experiments in which partial regularities and values of quantities serving as a basis for further calculations are determined, it is necessary that the probability achieves $99 \%$ [34]. 
The following relationship can be used to determine the required number of set repeats [13]:

$$
n=\frac{N \cdot t_{a}^{2} \cdot s^{2}}{t_{a}^{2} \cdot s^{2}+N \cdot \Delta}
$$

where:

$N$ is the extent of the set used.

This calculation method can also be used for the base set, because at values $N>10^{6}$, the required number of repetitions $n$ further increases very slightly.

If the coefficient of variation of the set $v_{k}$ is known, then the required number of repetitions can be determined according to the relation:

$$
n=\frac{v_{k}^{2} \cdot t_{a}^{2}}{\delta^{2}}
$$

where:

$n$ is the number of repetitions detected;

$t_{a}$ is the critical value of the normal distribution for a bilateral estimate;

$v_{k}$ is the coefficient of variation, \%;

$\delta$ is the maximum permissible error, $\%$.

For a known value of the coefficient of variation, it is possible to determine the required number of repetitions using the ratio $\delta / v_{k}$.

As far as the measurement of one quantity is concerned, the task of the proposal is reduced to determine the number of repeated measurements. For repeated measurements under the same conditions, the number of measurements is determined either by the prescribed uncertainty of the measurement result or by the prescribed costs. The uncertainty of the measurement result is formed by the uncertainty evaluated by the type A method and the uncertainty evaluated by the type B method. The first component of uncertainty is affected by the number of measurements and the second component by the measurement method, measuring equipment, measurement conditions, etc. In order to achieve the expected uncertainty of the measurement result, we had to choose the appropriate method, measuring equipment, and measurement conditions. By the number of measurements, we were able to influence only the component of uncertainty determined by the type A method [35].

For repeated measurement under the same conditions for the measured values $X_{1}, X_{2}$, $\ldots, X_{n}$, the estimate of the value of the measured quantity is given by the arithmetic mean of the measured values (at zero corrections) and the uncertainty assessed by the type $\mathrm{A}$ method by:

$$
\mu_{A}=\frac{s}{\sqrt{n}}
$$

where:

$s$ is the selection standard deviation.

The sample standard deviation of the data is defined as the square root of the sample variance. We calculated the sample standard deviation from the realized selection, i.e., if we do not have a complete set of possible states but only a selection of them. For example, we measured the value of a certain physical quantity and repeated the measurement, e.g., 10 times. Because each equipment has its own prescribed accuracy class, the results of our measurements varied slightly at the lowest order locations. Then, we cannot determine the standard deviation for a small number of measurements. We must therefore consider $n-1$ in the formula (because 1 measurement is already dependent on the calculation of the mean value). For a large number of measurements, the difference between the standard and sample standard deviation is lost [36]. 
The sample standard deviation is then given by:

$$
s=\sqrt{\frac{1}{n-1} \sum_{i=1}^{n}\left(x_{i}-\bar{x}\right)^{2}}
$$

where:

$x_{i}$ is the measured values;

$\bar{x}$ is the arithmetic mean.

Equation (7) results in the recalculation of repeated measures characterized by the variance $s^{2}$ to achieve a given uncertainty component $\mu_{A}$ :

$$
n \geq\left(\frac{s}{\mu_{A}}\right)^{2}
$$

This means that if we want to reduce the uncertainty component of type A by $k$ times, we must increase the number of measurements $k$ by 2 times with constant variance $s^{2}$. Another way is to take measures to reduce the variance of measurements.

When measuring several quantities, we want to find a measurement proposal for which the uncertainties in determining the values of all quantities would be the smallest of all possible proposals. We call such a proposal evenly the best proposal. In reality, however, the existence of a uniformly best proposal is rare. Therefore, we must most often specify the goal of the experiment (measurements), and choose the appropriate proposal selection criterion [36].

2.5. Influence of the Tested Fuel on the Technical and Ecological Parameters of the LOMBARDINI LDW 502 Engine

The technical and ecological parameters of the LOMBARDINI LDW 502 engine were determined during the combustion of standard hydrocarbon fuel and two samples of alternative fuels. The engine is made by Lombradini a Kohler Company, Emilia, Italy. Diesel was the reference fuel on the basis of which the data obtained during the application and combustion of the alternative fuel SAMPLE 1 and SAMPLE 2 were compared with a new sample in the fuel system of the above engine.

The benchmarks for all fuels tested included:

- $\quad$ Torque $M_{k}, \mathrm{Nm}$;

- $\quad$ Corrected power $P_{\text {ekor }}, \mathrm{kW}$;

- Injected fuel dose, $\mu \mathrm{L} \cdot$ cylinder $^{-1} \cdot$ cycle $^{-1}$;

- $\quad$ Specific fuel consumption $m_{p e}, \mathrm{~g} \cdot \mathrm{kW}^{-1} \cdot \mathrm{h}^{-1}$;

- $\quad$ Thermal efficiency $\eta_{t}, \%$;

- Smoke value, $k, \mathrm{~m}^{-1}$;

- $\mathrm{NO}_{\mathrm{X}}$ emission value, ppm.

To determine the thermal efficiency of the engine $\eta_{t}$, it is necessary to know the energy, which is contained in the fuel $E_{p}$, which can be expressed by the relation:

$$
E_{p}=\frac{M_{p} \cdot H U}{3.6} \mathrm{~kJ} \cdot \mathrm{s}^{-1}
$$

where:

$M_{p}$ is the hourly fuel consumption, $\mathrm{kg} \cdot \mathrm{h}^{-1}$;

$\mathrm{HU}$ is the lower heat value of fuel, $\mathrm{MJ} \cdot \mathrm{kg}^{-1}$.

$$
\eta_{t}=\frac{P_{\text {ekor }}}{E_{p}} \cdot 100 \%
$$


Measurement of Technical and Ecological Parameters on the Test Engine for Discrete Measurement

Results of measurement of technical and ecological parameters of the engine on a test rig at steady state with fuel: diesel.

Conditions under which the measurements were made:

$\begin{array}{ll}\text { Laboratory temperature } & 24.2{ }^{\circ} \mathrm{C}=297.35 \mathrm{~K} \\ \text { Atmospheric pressure } & 99.17 \mathrm{kPa} \\ \text { Humidity } & 30.90 \% \\ \text { Fuel density-diesel } & 0.84 \mathrm{~g} \cdot \mathrm{cm}^{-3} \\ \text { Fuel heat value-diesel } & 41.90 \mathrm{MJ} \cdot \mathrm{kg}^{-1}\end{array}$

Results of measurement of technical and ecological parameters of the engine on a test rig at steady state with fuel: SAMPLE 1:

Conditions under which the measurements were made:

Laboratory temperature

Atmospheric pressure

Humidity

Fuel density-SAMPLE 1

Fuel heat value-SAMPLE 1

$23.7^{\circ} \mathrm{C}=296.85 \mathrm{~K}$
$101.3 \mathrm{kPa}$
$26.57 \%$
$0.88 \mathrm{~g} \cdot \mathrm{cm}^{-3}$
$38.50 \mathrm{MJ} \cdot \mathrm{kg}^{-1}$

Results of measurement of technical and ecological parameters of the engine on a test rig at steady state with fuel: SAMPLE 2:

Conditions under which the measurements were made:

$\begin{array}{ll}\text { Laboratory temperature } & 24{ }^{\circ} \mathrm{C}=297.15 \mathrm{~K} \\ \text { Atmospheric pressure } & 101.5 \mathrm{kPa} \\ \text { Humidity } & 31.27 \% \\ \text { Fuel density-SAMPLE 2-new sample } & 0.88 \mathrm{~g} \cdot \mathrm{cm}^{-3} \\ \text { Fuel heat value-SAMPLE 2-new sample } & 38.00 \mathrm{MJ} \cdot \mathrm{kg}^{-1}\end{array}$

\section{Results}

Evaluation of Measured Data from Tests of Tested Fuels on a Test Device at Steady State Mode with the LOMBARDINI LDW 502 Test Engine

Statistically, the minimum number of measurements was calculated to be three. We performed seven measurements for each tested fuel. The correction factor was calculated according to Formula (1), valid for EGG 80/1269, which is used for non-supercharged engines. If the motor has no engine factor, the parameter is specified according to the engine type, the engine factor is set at 0.3 also in accordance with the manufacturer's recommendations. The operating conditions for the tests were as follows:

The engine temperature during the measurement ranged from 80 to $92{ }^{\circ} \mathrm{C}$, and the speed range during loading was from 1200 to $3200 \mathrm{~min}^{-1}$. The tests were performed according to ISO 2288, STN 30 0415, and STN ISO 789-1 (30 0411).

Based on the measured data of the tested fuels, the graphical dependences of the compared samples of biofuels with the reference fuel were constructed. The results of the measurements are recorded in graphical form in Figures 2-6.

Figure 2 shows the relationship of torque and fuel injection to rpm for diesel fuels SAMPLE 1 and SAMPLE 2. It can be seen from the graphic expression that there are minimal differences between the individual fuels, both during the torque curves and in the achieved torque values. The torque values for SAMPLE 1 fuel were increased by $2.4 \%$ at $3200 \mathrm{rpm}$ compared to diesel fuel; however, in the speed range at maximum torque, a decrease of $0.3 \%$ was recorded, which is a negligible value. It is worth mentioning the recorded value of torque at the speed of $2800 \mathrm{rpm}$ and the course of the torque curve from the speed of $1600 \mathrm{rpm}$ to the speed of $1200 \mathrm{rpm}$ for the mentioned tested fuel. The increase in torque at $2800 \mathrm{rpm}$ as a linear course of torque in the speed range from 1600 to $1200 \mathrm{rpm}$ is due to the amount of fuel injected per cycle, which is directly proportional to the hourly fuel consumption $M_{p}$ and inversely proportional to the engine speed $n$ and the density of the fuel $\rho$. 
When comparing SAMPLE 2 fuel with the reference diesel fuel (Figure 2), minimal differences were found during the torque, as well as in the achieved values. The range of torque reduction for SAMPLE 2 fuel is from 0.33 to $2 \%$ compared to diesel.

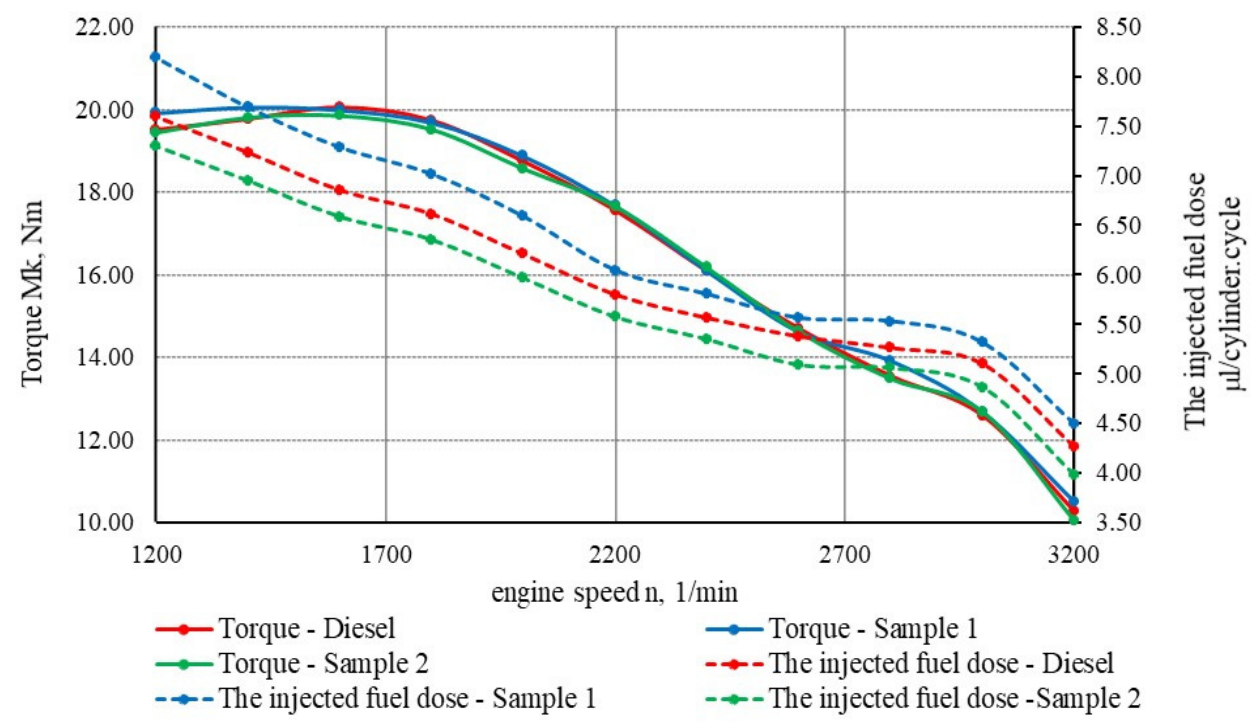

Figure 2. Comparison of the course of torque and injected fuel dose with tested fuels on the LOMBARDINI LDW 502 engine.

Regarding the comparison of the injected fuel dose per cylinder and cycle (Figure 2), for SAMPLE1, the value increased from 3\% to $7 \%$ compared to the reference diesel. In contrast, with SAMPLE 2 fuel, there was a reduction in the fuel injection in the range of $4 \%$ to $7 \%$ compared to diesel.

As indicated above, the amount of fuel injected per cylinder and cycle is significantly affected by the bulk density of the fuel. which is also confirmed by the relationship for the calculation of the injected fuel dose (11):

$$
V_{v}=\frac{10^{6} \cdot M_{p}}{2.60 \cdot n \cdot \rho} \mu \mathrm{L} / \text { cylinder } \cdot \text { cycle }
$$

where:

$V_{v}$ is the fuel injection, $\mu \mathrm{L} /$ cylinder-cycle;

$P$ is the fuel density, $\mathrm{kg} \cdot \mathrm{dm}^{-3}$;

$M_{p}$ is the hourly fuel consumption, $\mathrm{kg} \cdot \mathrm{h}^{-1}$.

The interdependencies between the rpm, torque, and injected dose for the tested fuels in a 3D view on the LOMBARDINI LDW 502 engine are shown in Figure 3.

An evaluation of the tested biofuels was also performed on the basis of a mutual comparison of the achieved effective power $P_{e}$ and energy supplied in the fuel $E_{p}$. The results of the mutual comparison are shown in graphical form in Figure 4. From the external speed characteristic of the LOMBARDINI LDW 502 engine (Figure 4), it can be seen that the effective engine power is constant in the speed range from 2000 to $3000 \mathrm{rpm}$.

When comparing the achieved power on the LOMBARDINI LDW 502 engine when applying SAMPLE 1 fuel, it can be stated that in the rpm range at which the abovementioned diesel engine achieves constant values of effective power, there was a decrease in power ranging from $1.76 \%$ to $2.84 \%$ compared to diesel. In the speed range from 1200 to $2000 \mathrm{rpm}$, a decrease in power from $0.5 \%$ to $2.5 \%$ was recorded.

A decrease in effective power was also observed when SAMPLE 2 fuel was applied. In the speed range from 2000 to $3000 \mathrm{rpm}$, a decrease in effective power in the range from $2 \%$ to $3 \%$ was recorded. At $3200 \mathrm{rpm}$, power decreased by approximately 5\% and in the speed range from 1200 to $2000 \mathrm{rpm}$, a decrease in power from 3\% to 4\% was recorded. 
When comparing the energy supplied in the fuel $E_{p}$ (Figure 4 ), it can be seen that the highest value is reached by the fuel curve-SAMPLE 1. Compared to diesel fuel, the curve of energy supplied in the fuel with the above-mentioned alternative fuel is higher in the range from $2 \%$ to $6 \%$. A lower decrease in the compared indicator was recorded for fuel SAMPLE 2. For this fuel, a decrease in the energy supplied in the fuel in the range from $2 \%$ to $6 \%$ was recorded compared to diesel. The indicator 'energy supplied in fuel $E_{p}{ }^{\prime}$ is affected by the hourly fuel consumption and the lower heat value of the fuel, as expressed by the relationship (9).

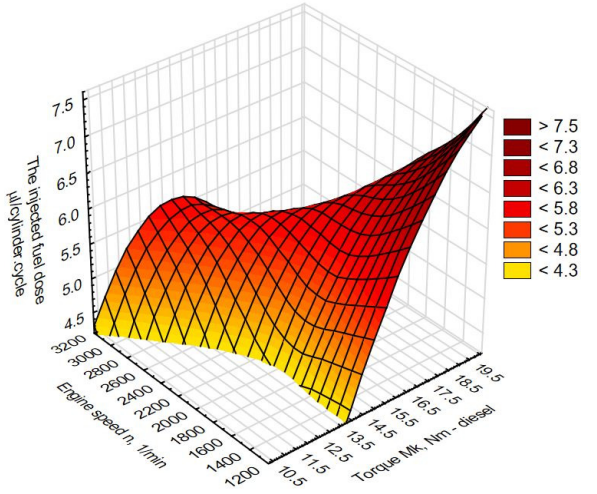

(a)

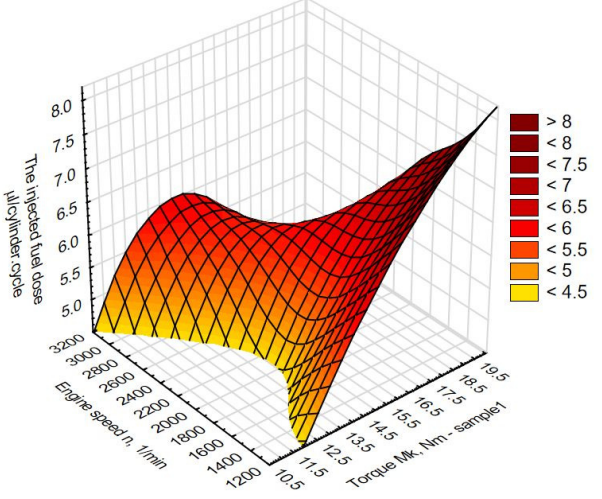

(b)

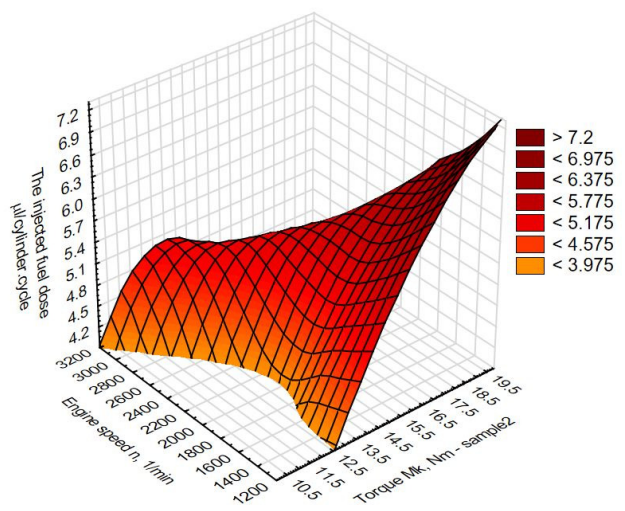

(c)

Figure 3. Interdependence of rpm, torque, and injection. (a) DIESEL, (b) SAMPLE 1, (c) SAMPLE 2.

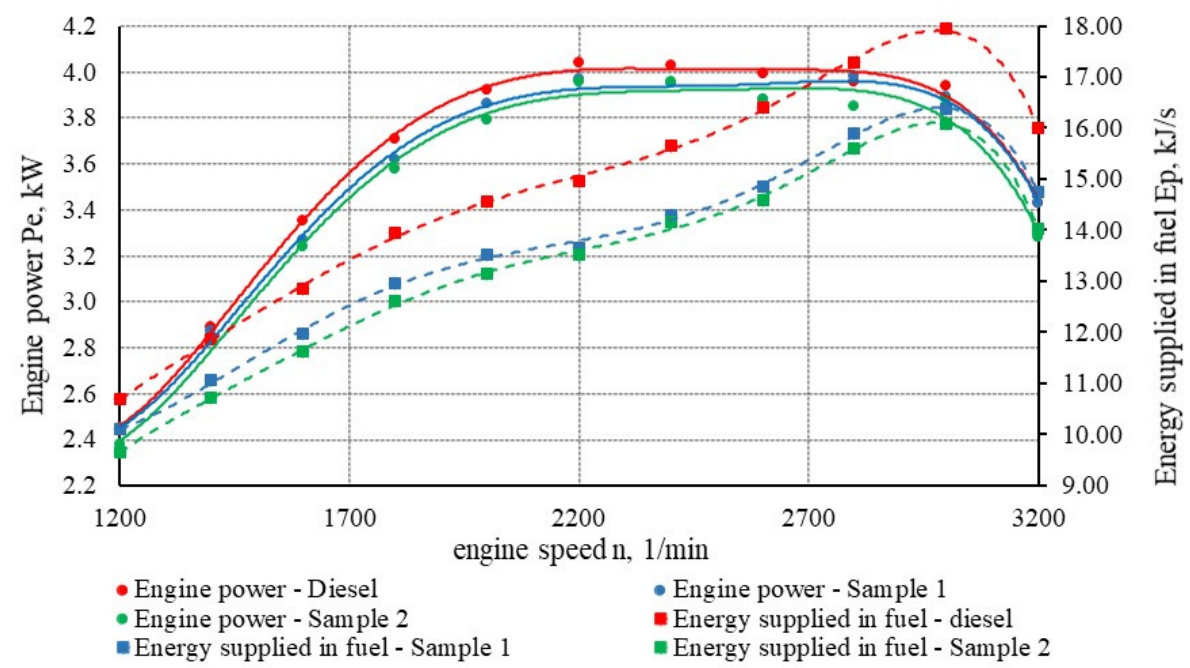

Figure 4. Comparison of the course of power and energy delivered in the fuel with the tested fuels on the LOMBARDINI LDW 502 engine. 
The interdependencies between the rpm, torque, and injected dose in the 3D view for the fuels tested on the LOMBARDINI LDW 502 engine are shown in Figure 5.

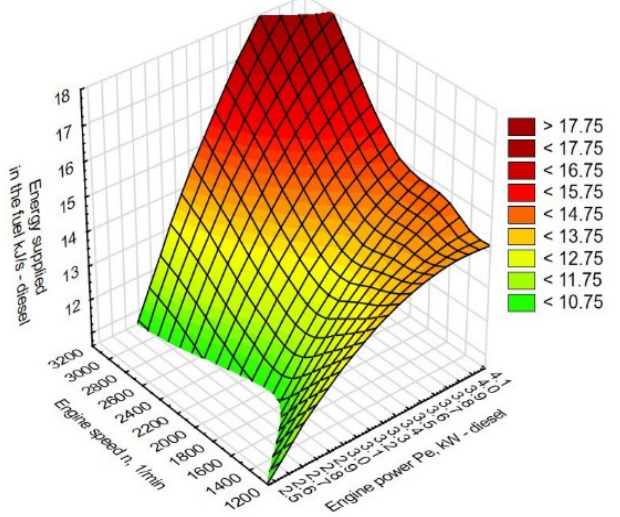

(a)

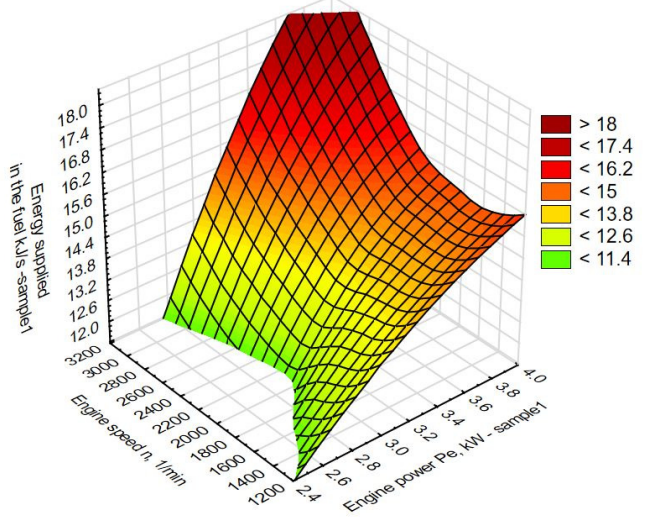

(b)

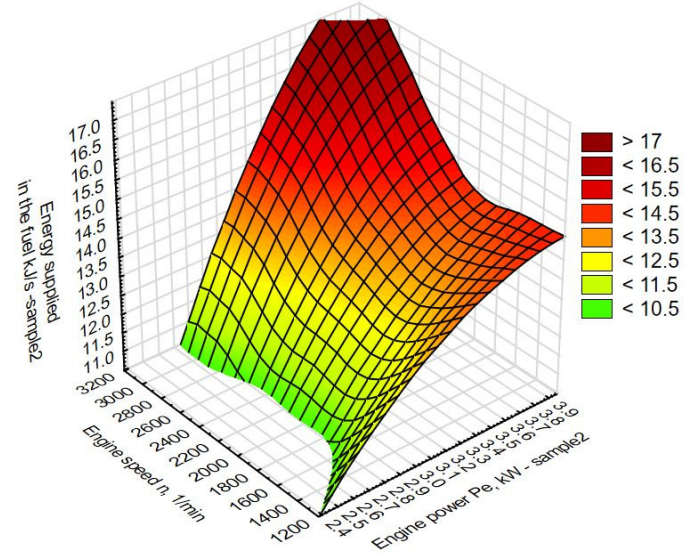

(c)

Figure 5. Interdependence of rpm, power, and energy supplied in the fuel. (a) DIESEL, (b) SAMPLE 1, (c) SAMPLE 2.

Other indicators that were evaluated from the point of view of biofuel testing are the specific fuel consumption $m_{p e}$ and the thermal efficiency of the CI engine $\eta_{c}$ (Figure 6).

The reference diesel fuel reached the lowest value of specific fuel consumption compared to the compared samples of biofuels. In the SAMPLE 1 sample, the value of specific fuel consumption was higher, in the range from $9 \%$ to $12 \%$. The highest difference in specific consumption was recorded in the speed range from 1200 to $2000 \mathrm{rpm}$.

The values of specific consumption with SAMPLE 2 fuel were higher compared to diesel, in the range from $0.7 \%$ to $4 \%$. The highest difference in specific consumption was recorded as in the previous case in the speed range from 1200 to $2000 \mathrm{rpm}$.

When comparing the tested fuels from the point of view of the thermal efficiency of the LOMBARDINI LDW 502 engine, it can be stated that the highest efficiency was achieved by the diesel engine at $2200 \mathrm{rpm}$ at all tested fuels. The results were calculated from the measured values according to Formulae (9) and (10). At the indicated rpm, the combustion engine operates with the lowest specific fuel consumption. The highest thermal efficiency at $2200 \mathrm{rpm}$ was achieved by the combustion engine with diesel fuel. In the SAMPLE 2 fuel tests, a decrease in thermal efficiency of only $1.4 \%$ was recorded at $2200 \mathrm{rpm}$. Compared to diesel, the value of thermal efficiency decreased from $27 \%$ to $26.6 \%$. 

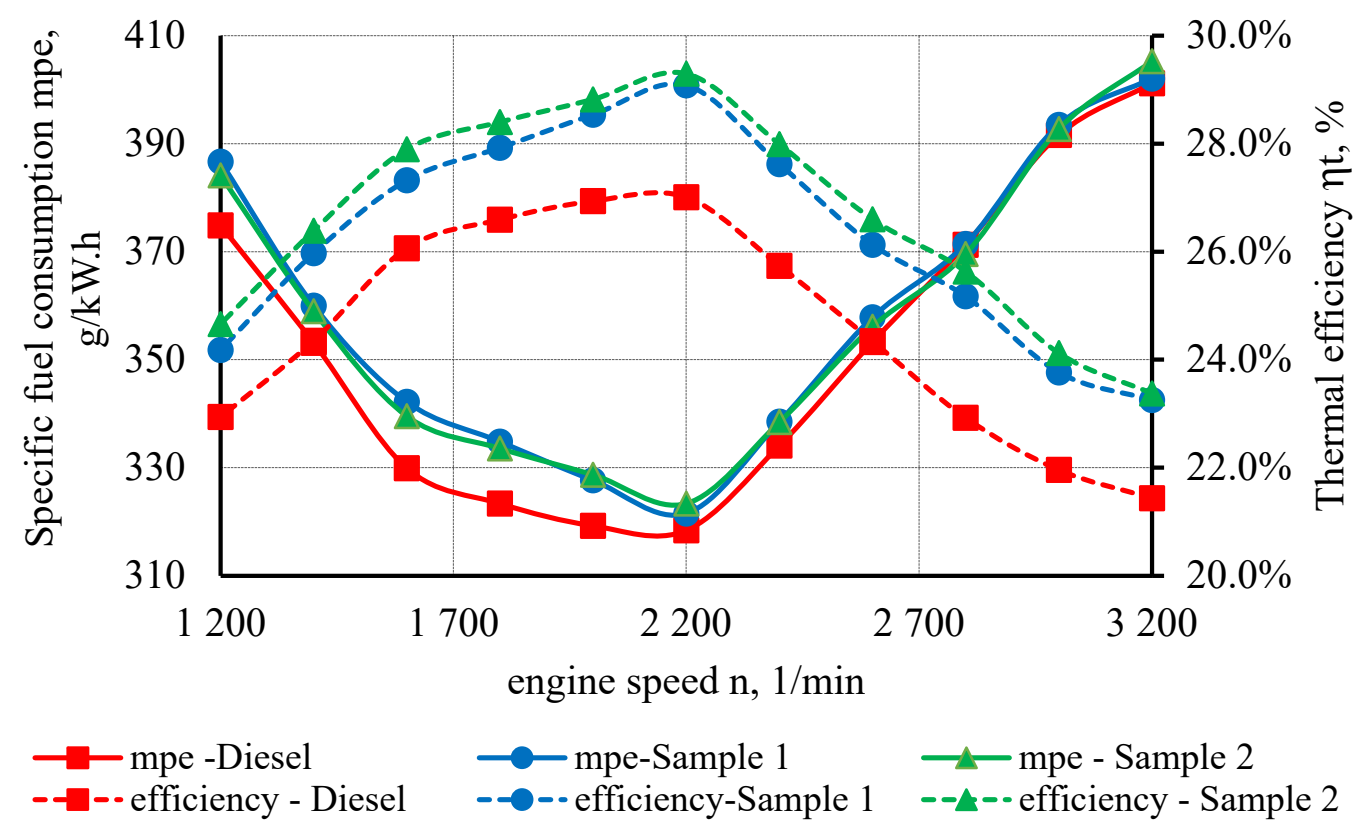

$$
\begin{array}{ll}
\longrightarrow \text { mpe-Sample } 1 & - \text { mpe - Sample } 2 \\
-\rightarrow-\text { efficiency-Sample } 1 \quad--4-\text { efficiency - Sample } 2
\end{array}
$$

Figure 6. Comparison of the course of specific fuel consumption and thermal efficiency with tested fuels on the LOMBARDINI LDW 502 engine.

When SAMPLE 1 was applied, the value of the thermal efficiency compared to diesel was reduced by $5.6 \%$ at $2200 \mathrm{rpm}$.

The course, as well as the size of the thermal efficiency of the diesel engine is given by the ratio of effective power and energy supplied in the fuel, as given by the relation $\eta_{c}$, which is given in Section 2.5.

From the measured smoke data, it is clear that the range of the MAHA MDO-2 Lon Euro did not allow measurement of the smoke values for SAMPLE 1 and SAMPLE 2 fuels at individual load points of the diesel engine. For this reason, $\mathrm{NO}_{\mathrm{X}}$ emission values were monitored and recorded as the LOMBARDINI LDW 502 diesel engine was gradually loaded. A comparison of the measured $\mathrm{NO}_{\mathrm{X}}$ emissions from diesel and two alternative fuels is shown in Figure 7.

It was not possible to assess the emission state from the point of view of the absorption coefficient on the tested internal combustion engine. The reason was the low values of the absorption coefficient in the tested samples, which the measuring device could not detect.

A situation in which the analyzer is unable to evaluate the absorption coefficient values also occurs in vehicles equipped with after-treatment devices (EURO 5, EURO 6). Due to the impossibility of assessing the emission state of the diesel engine by measuring the absorption coefficient caused by exhaust gas filtration, it was necessary to find another alternative method of assessing the emission state of the diesel engine. This study focused on NOx emissions in accordance with the requirements of the biofuel sample manufacturer. In the future, NOx emissions may be used to assess the emission status of an internal combustion engine together with methods for detecting malfunctioning, damaged, or dismantled exhaust after-treatment devices.

As can be seen from the graphical comparison of the measured emissions of nitrogen oxides $\mathrm{NO}_{\mathrm{X}}$ (Figure 7) under the load of the diesel engine, it can be stated that nitrogen oxides are higher for both tested alternative fuels than for the reference fuel. The average value of nitrogen oxides recorded when loading the LOMBARDINI LDW 502 powered by diesel reached $212 \mathrm{ppm}$. The measured value is $4.5 \%$ lower than the average value of $\mathrm{NO}_{X}$ emissions with the alternative fuel SAMPLE 1 and $7.42 \%$ lower than the average $\mathrm{NO}_{X}$ emissions of the alternative fuel SAMPLE 2 (Figure 8). 


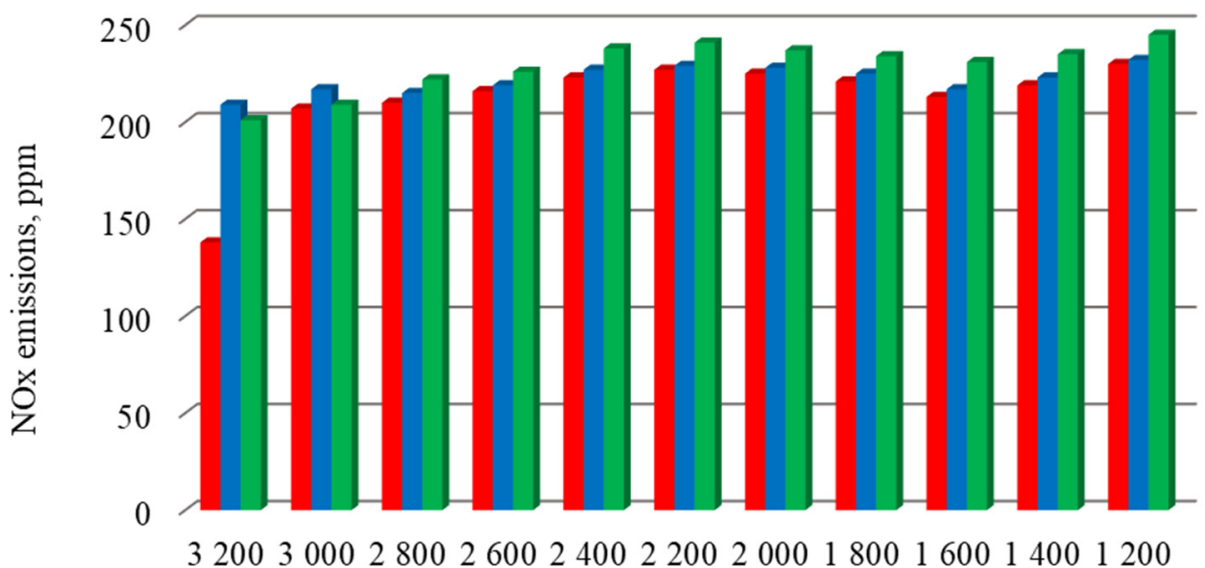

Engine speed n, 1/min

- Diesel $\square$ Sample 1 - Sample 2

Figure 7. Comparison of $\mathrm{NO}_{X}$ emissions with tested fuels on the engine LOMBARDINI LDW 502 under its load.

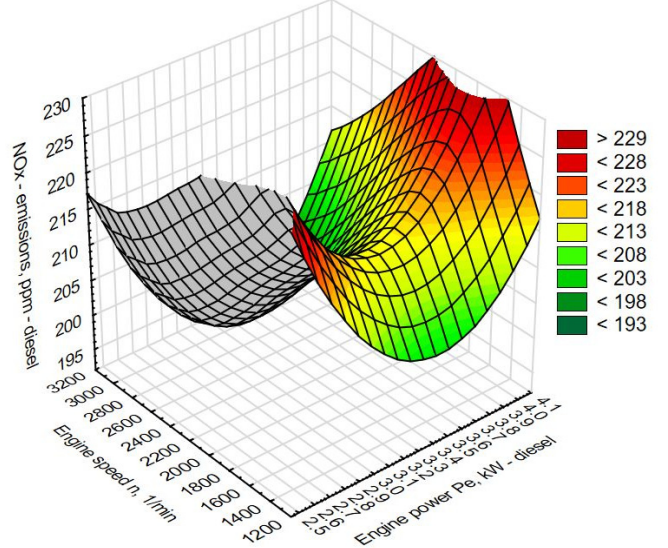

(a)

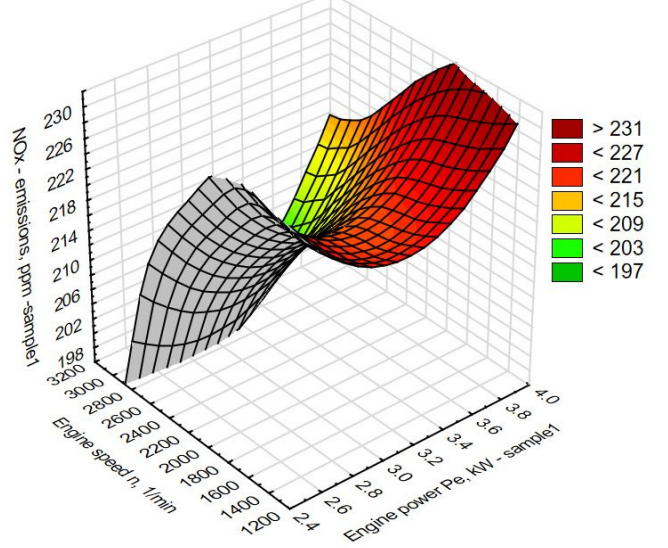

(b)

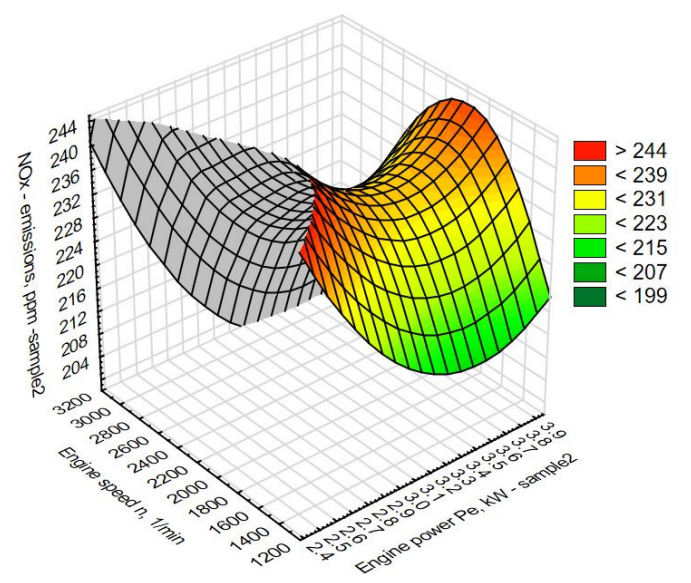

(c)

Figure 8. Interdependence of speed, corrected power, and $\mathrm{NO}_{X}$ emissions. (a) DIESEL, (b) SAMPLE 1, (c) SAMPLE 2. 


\section{Discussion}

In the submitted study, two types of alternative fuels, SAMPLE 1 and SAMPLE 2, were compared with diesel as a reference fuel. The comparison of the above-mentioned alternative fuels was intended to monitor their impact on technical parameters, environmental parameters, and economy of the internal combustion engine.

The significant impact regarding the technical parameters of the internal combustion engine when using biofuel as an energy source will be its physicochemical properties. The throughput of an internal combustion engine is affected by the properties of biofuel, in particular its caloricity, viscosity, and lubricating properties. The calorific value of fuels is an important indicator, which affects the release of energy for labor production. The lower calorific value of biodiesel is related to the decrease in engine throughput.

The calorific value of fuels is in an important indicator that affects energy release for labor production. A lower calorific value of biodiesel is related to a decrease in engine throughput. This finding can be confirmed with the test results for fuels SAMPLE 1 and SAMPLE 2, which compared to diesel fuel had a lower calorific value, as well as lower achieved throughput. As for viscosity, we can agree with [14,36], who reported that higher viscosity is the cause of throughput loss, as higher viscosity reduces combustion efficiency due to impaired fuel injection atomization. The authors' opinion can be confirmed given that the tested fuels SAMPLE 1 and SAMPLE 2 showed a higher viscosity value than diesel and, as stated earlier, the conducted measurements confirmed a decrease in throughput.

Specific fuel consumption was the next parameter that was monitored when comparing the fuels SAMPLE 1 and SAMPLE 2. From the achieved results of specific fuel consumption, it can be stated that both tested fuels had a higher consumption rate compared to diesel. Specifically, the SAMPLE 1 fuel recorded an increase in specific fuel consumption by an average of $10.6 \%$ and the SAMPLE 2 fuel by $2.6 \%$. The increase in the specific consumption rate of the tested fuels is caused by their lower caloricity and their higher specific weight compared to diesel. Comparable results were also achieved by $[37,38]$, who agrees with the notion that a lower calorific value of biodiesel must be offset by a higher consumption rate.

While testing alternative fuels, the measurement of $\mathrm{NO}_{x}$ emissions was also conducted and focused on. Emissions of nitrogen oxides are significantly influenced by the cetane number of the fuel, the amount of oxygen contained in the fuel, raw material used in the production of the biofuel, and lastly by the injection advance value. As previously mentioned, the cetane number has an effect on the amount of nitrogen oxide $\mathrm{NO}_{\mathrm{X}}$ emissions. The tested alternative fuels SAMPLE 1 and SAMPLE 2 have higher values of the cetane number compared to diesel. A higher cetane number results in shortening of the ignition delay, which leads to better combustion but at the same time increases the production of nitrogen oxide $\mathrm{NO}_{\mathrm{X}}$ emissions. This statement is also confirmed in the papers [39-44]. Some studies attributed high $\mathrm{NO}_{X}$ emissions of biodiesel to a single influencing factor. This increased $\mathrm{NO}_{\mathrm{X}}$ tendency was attributed to the increased oxygen levels of biofuels, which leads to a higher cylinder temperature [45-47].

The oxygen levels of biodiesel result in an increase of the production of nitrogen oxides. The results of the experimental measurements performed on a diesel engine done by [48] probed the relationship between nitrogen oxide levels and oxygen content in fuel.

\section{Conclusions}

Currently, when our environment is overburdened with emissions of all kinds, the idea of using fuels with minimal impact on the environment is becoming very important. Fuels made from the methyl ester of seed oil can be considered advantageous mainly from the point of view that almost every diesel engine is, in principle, capable of burning such fuels. If we take into account the fact that up to $90 \%$ of the transport of people and goods is currently carried out by means of diesel vehicles (trucks, buses, locomotives, ships, tractors), it represents a huge potential. In addition, there are a large number of passenger cars equipped with diesel engines, which could also use fuels made from the methyl ester 
of seed oils for propulsion. In the countries of the European Union, their number ranges from 15 to $40 \%$. Very often, the contribution of fuels produced from plant origin in terms of creating a balance of carbon dioxide circulation in nature is emphasized. The production of carbon dioxide during combustion corresponds to its consumption during photosynthesis. Biodegradability, e.g., rapeseed oil methyl ester after its release into the environment, is approximately $95 \%$ in 6 days.

The second part presents the results of the application of alternative fuels SAMPLE 1, SAMPLE 2, and their impact on the technical parameters, environmental parameters, and economy of the diesel engine. Based on the results of the measurement, their evaluation, as well as other significant facts that were found, it can be stated that when using biofuels as an energy source for the propulsion of vehicles equipped with a diesel engine, there is a decrease in power in the range from 1.5 to $3.8 \%$. As for the specific fuel consumption, it increased by a maximum of $12 \%$ with the tested SAMPLE 1 fuel and for SAMPLE 2, a maximum increase of $4 \%$ was recorded.

Other important indicators from an ecological point of view are smoke values as well as $\mathrm{NO}_{\mathrm{X}}$ emission values. The measurement of smoke values was performed at steady state with the load of the diesel engine. When measuring smoke at steady state when the combustion engine is loaded, it was not possible to evaluate the measurements in regard to the small volume of the diesel engine and also the limited range of the analyzer on which the measurements were made. From an ecological point of view, the values of nitrogen oxide emissions are also important. $\mathrm{NO}_{\mathrm{X}}$ emission values were recorded in $\mathrm{ppm}$ and subsequently converted to $\mathrm{g} \cdot \mathrm{kW}^{-1} \cdot \mathrm{h}^{-1}$. Measurements of $\mathrm{NO}_{\mathrm{X}}$ emissions were performed at steady state with the diesel engine loaded. Their increase was recorded, with the alternative fuel SAMPLE 1 by $4.5 \%$ and with the alternative fuel SAMPLE 2 by $7.42 \%$ compared to the diesel fuel. In this case, nitrogen oxides were recorded in ppm.

As has been mentioned several times, the exhaust emissions of a diesel engine have a negative impact on the environment as well as on humans. These are mainly emissions of pollutants, especially "greenhouse" gases, which cause the gradual irreversible warming of the planet and upset the balance in nature with acid rain. This is mainly carbon dioxide $\mathrm{CO}_{2}$, nitrogen oxides $\mathrm{NO}_{\mathrm{X}}$, methane $\mathrm{CH}_{4}$, and sulfur oxides $\mathrm{SO}_{\mathrm{X}}$. Promoting the use of alternative fuels in transport is a step towards greater use of biomass, which will allow for a wider improvement of alternative fuels in the future, without excluding other options and in particular the possibility of using hydrogen.

Author Contributions: Conceptualization, J.J.; writing—original draft preparation, J.J.; methodology, J.J., J.T. and L.H.; formal analysis, Z.T., P.F. and J.K.; writing-review and editing, P.F. and J.T.; visualization, L.H., P.K. and M.T. All authors have read and agreed to the published version of the manuscript.

Funding: This research received no external funding.

Institutional Review Board Statement: Not applicable.

Informed Consent Statement: Not applicable.

Acknowledgments: This work was supported by AgroBioTech Research Centre built in accordance with the project Building "AgroBioTech" Research Centre ITMS 26220220180. This publication was supported by the Operational Program Integrated Infrastructure within the project: Demand-driven research for the sustainable and innovative food, Drive4SIFood 313011V336, cofinanced by the European Regional Development Fund.

Conflicts of Interest: The authors declare that they have no known competing financial interests or personal relationships that could have appeared to influence the work reported in this paper. 


\section{References}

1. Markulík, S.; Šolc, M.; Petrík, M.; Balážiková, M.; Blaško, P.; Kliment, J.; Bezák, M. Application of FTA Analysis for Calculation of the Probability of the Failure of the Pressure Leaching Process. Appl. Sci. 2021, 11, 6731. [CrossRef]

2. Markulík, S.; Nagyová, A.; Turisová, R.; Vilinský, T. Improving Quality in the Process of Hot Rolling of Steel Sheets. Appl. Sci. 2021, 11, 5451. [CrossRef]

3. Official Statistics of Finland (OSF). Greenhouse Gases; Official Statistics of Finland (OSF): Helsinki, Finland, 2020 ; ISSN 1797-6065.

4. Tkáč, Z.; Gaduš, J.; Jablonický, J.; Abrahám, R.; Bohát, M. Alternatíone Palivá pre Motory; Slovak University of Agriculture in Nitra: Nitra, Slovakia, 2008; ISBN 978-80-552-0095-8.

5. Jablonický, J.; Tkáč, Z.; Tulík, J.; Uhriniva, D.; Polerecký, J. Automobilové Spal'ovacie Motory; Slovak University of Agriculture in Nitra: Nitra, Slovakia, 2019; ISBN 978-80-552-2015-4.

6. Qi, D.H.; Chen, H.; Geng, L.M.; Bian, Y.Z.H. Experimental studies on the combustion characteristics and performance of a direct injection engine fueled with biodiesel/diesel blends. Energy Convers. Manag. 2010, 51, 2985-2992. [CrossRef]

7. Tat, E.M.; Gerpen Van, J.H.; Wang, P.S. Fuel Property Effects on Injection Timing, Ignition Timing, and Oxides of Nitrogen Emissions from Biodiesel-Fueled Engines. Agris: International Information System for the Agricultural Science and Technology. 2011 Available online: http:/ / web.cals.uidaho.edu/biodiesel/files/2013/08/Trans-50_4_1123.pdf (accessed on 21 September 2021).

8. Armas, O.; Yehliu, K.; Boehman, A.L. Effect of alternative fuels on exhaust emissions during diesel engine operation with matched combustion phasing. Fuel 2010, 89, 438-456. [CrossRef]

9. ACEA Biodiesel Guidelines; European Automobile Manufacturers Association: Brussels, Belgium, 2009.

10. Gums, M.; Kasifoglu, S. Performance and emission evaluation of compression ignition engine using a biodiesel (apricot seed kernel oil methyl ester) and its blends with diesel fuel. Biomass Energy 2010, 34, 134-139. [CrossRef]

11. Lend'ák, P.; Švec, J.; Jablonický, J. Application of measurement methods of solid particle emission of diesel engine and their mutual comparation. Acta Technol. Agric. 2007, 2, 29.

12. Králik, M.; Jablonický, J.; Nikolov, M.I. Monitoring of $\mathrm{NO}_{X}$ Emissions at Selected Diesel Engine; University of Ruse "Angel Kanchev": Ruse, Bulgaria, 2015; ISBN 978-954-712-678-7.

13. Šmerda, T.; Čupera, J.; Fajman, M. Vznětové Motory Vozidel. Biopaliva, Emise, Traktory; CPress Brno: Brno, Czech Republic, 2013; ISBN 978-80-264-0160-5.

14. Tauzia, X.; Maiboom, A.; Shah, S.R. Experimental study of inlet manifold water injection on combustion and emissions of an automotive direct injection diesel engine. Energy 2010, 35, 3628-3639. [CrossRef]

15. Hammond, G.P.; Kallu, S.; McManus, M.C. Development of biofuels for the UK automotive market. Appl. Energy 2007, 85, 506-515. [CrossRef]

16. Utlu, Z.; Kocak, M.S. The effect of biodiesel fuel obtained from waste frying oil on direct injection diesel engine performance and exhaust emissions. Renew. Energy 2008, 33, 1936-1941. [CrossRef]

17. Dorado, M.P.; Ballesteros, E.; Arnal, J.M.; Gómez, J.; López, F.J. Exhaust emissions from a diesel engine fueled with transesterified waste olive oil. Fuel 2003, 82, 1311-1315. [CrossRef]

18. Gunasekar, P.; Manigandan, S.; TR, P.K. Hydrogen as the futuristic fuel for the aviation and aerospace industry-Review. Aircr. Eng. Aerosp. Technol. 2020, 93, 410-416. [CrossRef]

19. Tesfa, B.; Mishra, R.; Zhang, C.; Gu, F.; Ball, A.D. Combustion and performance characteristics of CI (compression ignition) engine running with biodiesel. Energy 2013, 51, 101-115. [CrossRef]

20. Mofijur, M.; Masjuki, H.H.; Kalam, M.A.; Atabani, A.E.; Shahabuddin, M.; Palash, S.M.; Hazrat, M.A. Effect of biodiesel from various feedstocks on combustion characteristics engine durability and materials compatibility: A review. Renew. Sustain. Energy Rev. 2013, 28, 441-455. [CrossRef]

21. Abdulaziz, A.K.; Asad, S.; Abdallah, M.E.; Darshan, D.D.; Rajasree, S.; Kathirvel, B. Experimental assessment of performance, combustion and emission characteristics of diesel engine fueled by combined non-edible blends with nanoparticles. Fuel 2021, $295,120590$.

22. Manigandan, S.; Gunasekar, P.; Devipriya, J.; Nithya, S. Emission and injection characteristics of corn biodiesel blends in diesel engine. Fuel 2019, 235, 723-735. [CrossRef]

23. Balat, M.; Balat, H. Progress in biodiesel processing. Appl. Energy 2010, 87, 1815-1835. [CrossRef]

24. Dhas, A.A.; Casmir, A.; Sattar, S.; Amjad, S.M.; Joy, N.; Alagu, K.; Renita, A. Effect of mixing two biodiesels on emissions in CI engine fuelled by candle nut and soap nut methyl esters-diesel blends. AIP Conf. Proc. 2020, 2311, 020013.

25. Sharma, P.K.; Sharma, D.; Soni, S.L.; Jhalani, A.; Singh, D.; Sharma, S. Energy, exergy, and emission analysis of a hydroxyl fueled compression ignition engine under dual fuel mode. Fuel 2020, 265, 116923. [CrossRef]

26. Sarıkoç, S.; Örs, İ.; Ünalan, S. An experimental study on energy-exergy analysis and sustainability index in a diesel engine with direct injection diesel-biodiesel-butanol fuel blends. Fuel 2020, 268, 117321. [CrossRef]

27. Gad, M.S.; EL-Seesy, A.I.; Radwan, A.; He, Z. Enhancing the combustion and emission parameters of a diesel engine fueled by waste cooking oil biodiesel and gasoline additives. Fuel 2020, 269, 117466. [CrossRef]

28. Ramadhas, A.S.; Muraleedharan, C.; Jayaraj, S. Performance and emission evaluation of a diesel engine fueled with methyl esters of rubber seed oil. Renew. Energy 2005, 30, 1789-1800. [CrossRef]

29. Qi, D.H.; Geng, L.M.; Chen, H.; Bian, Y.Z.; Liu, J.J.; Ren, X.C. Combustion and performance evaluation of a diesel engine fueled with biodiesel produced from soybean crude oil. Renew. Energy 2009, 34, 2706-2713. [CrossRef] 
30. Frijters, P.J.M.; Baert, R.S.G. Oxygenated fuels for clean heavy-duty engines. Int. J. Veh. Des. 2006, 41, 242-255. [CrossRef]

31. Jablonický, J.; Hujo, L'. Laboratórne Testovacie Zariadenia na Sledovanie Prietokovej Účinnosti Filtrov pri Aplikácii Biopalív so Simulovaním Prevádzkových Podmienok. Patent SK 288629 B6, 8 January 2019.

32. Ranjeet, K.R.; Sahoo, R.R. Engine performance, emission, and sustainability analysis with diesel fuel-based Shorea robusta methyl ester biodiesel blends. Fuel 2021, 292, 120234.

33. Dhar, A.; Kevin, R.; Agarwal, A.K. Production of biodiesel from high-FFA neem oil and its performance, emission and combustion characterization in a single cylinder DICI engine. Fuel Process. Technol. 2012, 97, 118-129. [CrossRef]

34. Can, Ö. Combustion characteristics, performance, and exhaust emissions of a diesel engine fuelled with a waste cooking oil biodiesel mixture. Energy Convers. Manag. 2014, 87, 676-686. [CrossRef]

35. Jablonický, J.; Tkáč, Z.; Majdan, R.; Uhrinová, D.; Hujo, L'; Vozárová, V. Properties Evaluation of Biofuels and Bio-Lubricants; Slovak University of Agriculture in Nitra: Nitra, Slovakia, 2012; ISBN 978-80-552-0766-7.

36. Rataj, V. Preparing a Scientific and Professional Text; Slovak University of Agriculture in Nitra: Nitra, Slovakia, 2003; ISBN 80-8069-162-2.

37. Palenčár, R.; Wimmer, G.; Palenčár, J.; Witkovský, V. Navrhovanie a Vyhodnocovanie Meraní; Slovak University of Technology: Bratislava, Slovakia, 2021; ISBN 978-80-227-5080-6.

38. Aydin, H.; Bayindir, H. Performance and Emission Analysis of Cottonseed Oil Methyl Ester in a Diesel Engine. Renew. Energy 2010, 35, 588-592. [CrossRef]

39. Al-Widyan, M.I.; Tashtoush, G.; Abu-Qudais, M. Utilization of ethyl ester of waste vegetable oils as fuel in diesel engines. Fuel Process. Technol. 2002, 76, 503-521. [CrossRef]

40. Kalligeros, S.; Zannikos, F.; Stournas, S.; Lois, E.; Anastopoulos, G.; Teas, C.; Sakellaropoulos, F. An investigation of using biodiesel/marine diesel blends on the performance of a stationary diesel engine. Biomass Bioenergy 2003, 24, 141-149. [CrossRef]

41. Özgünay, H.; Çolak, S.; Zengin, G.; Sari, Ö.; Sarikahya, H.; Yüceer, L. Performance and emission study of biodiesel from leather industry pre-fleshings. Waste Manag. 2007, 27, 1897-1901. [CrossRef]

42. Kwanchareaon, P.; Leungnaruemitchai, A.; Jai-In, S. Solubility of a diesel-biodiesel-ethanol blend, its fuel properties, and its emission characteristics from diesel engine. Fuel 2007, 86, 1053-1061. [CrossRef]

43. Lapuerta, M.; Armas, O.; Rodríguez, F.J. Effect of biodiesel fuels on diesel engine emissions. Prog. Energy Combust. Sci. 2008, 4, 198-223. [CrossRef]

44. Wu, F.; Wang, J.; Chen, W.; Shuai, S. A study on emission performance of a diesel engine fueled with five typical methyl ester biodiesels. Atmos. Environ. 2009, 43, 1481-1485. [CrossRef]

45. Tamilselvan, P.; Nallusamy, N.; Rajkumar, S. A comprehensive review on perfor mance, combustion and emission characteristics of biodiesel fuelled diesel engines. Renew. Sustain. Energy Rev. 2017, 79, 1134-1159. [CrossRef]

46. Patel, R.L.; Sankhavara, C.D. Biodiesel production from Karanja oil and its use in diesel engine: A review. Renew. Sustain. Energy Rev. 2017, 71, 464-474. [CrossRef]

47. Jiaqiang, E.; Pham, M.; Zhao, D.; Deng, Y.W.; Le, D.H.; Zuo, W.; Zhu, H.; Liu, T.; Peng, Q.G.; Zhang, Z.Q. Effect of different technologies on combustion and emissions of the diesel engine fueled with biodiesel: A review. Renew. Sustain. Energy Rev. 2017, 80, 620-647.

48. Labeckas, G.; Slavinskas, S. The effect of rapeseed oil methyl ester on directinjection diesel engine performance and exhaust emissions. Energy Convers. Manag. 2006, 47, 1954-1967. [CrossRef] 